John Carroll University

Carroll Collected

2020

Of Research reviews and practice guides: Translating rapidly growing research on adolescent literacy into updated practice recommendations.

Daniel Reynolds

Follow this and additional works at: https://collected.jcu.edu/fac_bib_2020

Part of the Education Commons 


\title{
Of Research Reviews and Practice Guides: Translating Rapidly Growing Research on Adolescent Literacy Into Updated Practice Recommendations
}

\begin{abstract}
A B S TR A C T
The demand for evidence-based instructional practices has driven a large supply of research on adolescent literacy. Documenting this supply, Baye, Inns, Lake, and Slavin's 2019 article in Reading Research Quarterly synthesized far more studies, with far more rigorous methodology, than had ever been collected before. What does this mean for practice? Inspired by this article, I investigated how this synthesis compared with the 2008 U.S. Institute of Education Sciences practice guide for adolescent literacy. I also include two contemporary documents for context: Herrera, Truckenmiller, and Foorman's (2016) review and the U.K. Education Endowment Foundation's 2019 practice guide for secondary schools. I first examine how these documents define adolescent, reading, and evidence, and propose more inclusive definitions. I then compare their respective evidence bases, finding that the quality and quantity of evidence have dramatically changed. Only one of the 34 studies in the 2008 U.S. practice guide met Baye et al.'s inclusion criteria in 2019, and the average sample size in Baye et al.'s studies was 22 times as large as those in the 2008 U.S. practice guide. I also examine the potential implications for a new practice guide's instructional recommendations and comment on the expansion of research in technology, disciplinary literacy, and writing-topics scarcely covered in the 2008 U.S. practice guide but which have been extensively researched since then. Finally, I call for revision of the U.S. practice guide and the establishment of standing committees on adolescent literacy to help educators translate the latest research findings into updated practices.
\end{abstract}

$\mathrm{I}$ $\mathrm{n}$ their review of quantitative research on reading programs for secondary students in issue of Reading Research Quarterly (RRQ), Baye, Inns, Lake, and Slavin (2019) noted,

Over the past decade, several reviews of research on secondary reading programs have provided an important base for the current synthesis. However, the surge in rigorous experiments is so recent that even the most current reviews are not up to date in terms of methodological quality of studies. (p. 135)

Even with stringent inclusion criteria, this review found 69 high-quality studies, more than double the number in previous reviews. In fact, those 69 studies included only four studies from a similar review published in $R R Q$ a decade earlier with two of the same authors (Slavin, Cheung, Groff, \& Lake, 2008). Baye and colleagues' synthesis of the new supply of research is likely to be much appreciated: As the authors noted, the demand for administrators, curriculum specialists, and teachers to select 
evidence-based instructional practices is also surging, partly because of the Every Student Succeeds Act (2015). Helping educators navigate the intersection of supply and demand for adolescent literacy evidence inspired me to write this commentary.

One document that helps educators navigate this intersection is the Institute of Education Sciences (IES) practice guide for improving adolescent literacy (Kamil et al., 2008), which "present[s] specific and coherent evidence-based recommendations that educators can use to improve literacy levels among adolescents in upper elementary, middle, and high schools" (p. 1). Based on this evidence, the guide's authors recommend five instructional practices: Provide explicit vocabulary instruction, provide explicit comprehension strategy instruction, provide opportunities for extended discussion of text meaning and interpretation, increase student motivation and engagement in literacy learning, and make available intensive and individualized interventions for struggling readers that can be provided by trained specialists. This guide is widely read among policymakers and has been cited hundreds of times by researchers, including Baye and colleagues (2019) and in other recent $R R Q$ articles (Boardman, Boelé, \& Klingner, 2018; Northrop \& Kelly, 2019; Proctor, Silverman, Harring, Jones, \& Hartranft, 2020).

Yet, new research has pushed the boundaries of the IES practice guide's recommendations. For example, the recommendations do not address disciplinary literacy, but more recent research has demonstrated that disciplinary literacy instruction can improve both disciplinary knowledge and literacy skills (Goldman et al., 2019; Reisman, 2012). In addition, Kamil and colleagues (2008) noted that the evidence for using discussion-based approaches was moderate, but more recent research has demonstrated the power of classroom discussion, especially for adolescents engaging in debates about big questions, analyzing multiple texts, and contrasting authorial perspectives (e.g., Imbrenda, 2018; Kim et al., 2017), suggesting that the evidence may now be more than moderate. Additionally, Kamil and colleagues devoted little attention to the role of writing, but a meta-analysis (Graham et al., 2018) suggested that writing can be a powerful tool for expanding adolescent literacy. These three contrasts are just a sample of ways that the last decade of literacy research might inform practice recommendations beyond the five found in the IES practice guide.

To understand how the full range of new of research might affect recommendations for practice, I investigated how the IES practice guide's (Kamil et al., 2008) definitions, evidence base, and recommendations compared with those of Baye and colleagues' (2019) more recent review. For context, I also used two other contemporary documents to understand changes in the evidence base for adolescent literacy practices: Herrera, Truckenmiller, and Foorman's (2016) IES-commissioned systematic review of the effectiveness of adolescent literacy programs, and a new practice guide just released by the Education Endowment Foundation (EEF; Quigley \& Coleman, 2019) in the United Kingdom. Because of the changes in the evidence base, I call for the IES to update Kamil et al's (2008) practice guide and consider implementing a standing committee on adolescent literacy to translate research to practice. This will help realize the promise of the extensive research investment into adolescent literacy.

\section{Comparing the Definitions of Adolescent, Reading, and Evidence}

\section{Who Is an Adolescent?}

\section{Age}

Kamil et al. (2008) and Baye et al. (2019) defined the age of adolescents differently. Kamil et al. explicitly justified their inclusion of fourth- and fifth-grade students "because their instructional needs related to literacy have more in common with those of students in middle and high school than they do with students in early elementary grades" (p. 1). In contrast, Baye and colleagues set their inclusion criteria beginning in sixth grade. Neither review offered a compelling rationale for their choices. Many empirical researchers would agree that a crucial distinction between elementary and adolescent reading is that instruction shifts from a focus on word identification to a focus on language comprehension (e.g., the simple view of reading; Gough \& Tunmer, 1986). Empirically, Foorman, Petscher and Herrera (2018) found that "above grade 4 , decoding had no unique contribution to reading comprehension" (p. 16). Similarly, in their meta-analysis, García and Cain (2014) synthesized 110 studies of a total of 42,891 readers ranging from 5 to 53 years old and found that the decoding-comprehension correlation decreased around age 10. The findings of these studies suggest that some researchers view reading profiles as changing toward adolescent literacy around fourth grade or age 10 .

Practice in the United States and internationally, however, suggests a slightly different perspective. Reviews of comprehension interventions for adolescents (e.g., Edmonds et al., 2009; Herrera et al., 2016; Slavin et al., 2008) have included grades 6-12 to align with the organization of U.S. middle and high schools. In addition, the EEF guide (Quigley \& Coleman, 2019) was written for U.K. secondary schools, which begin around age 11. Worldwide, according to the International Standard Classification of Education, secondary education begins at ages 10-13 (UNESCO Institute for Statistics, 2011). 
It seems that many authors of reviews and practice guides considered not only what reading researchers have said, but also the structure of the school systems that are their intended audience.

This connection to practice is echoed in the U.S. Common Core State Standards in English Language Arts (National Governors Association Center for Best Practices \& Council of Chief State School Officers, 2010). The Common Core shifts dramatically at grade 6: Foundational skills standards in word identification are specified for grades $\mathrm{K}-5$ and discontinued for grades 6-12, whereas standards for literacy in content areas are absent for grades K-5 but present for grades 6-12. Consequently, informed by developmental theories that guide school organization (i.e., that fourth and fifth graders are better considered primary rather than secondary students), practitioners may see adolescent literacy as beginning in sixth grade. Defining just when adolescence begins, and negotiating between the findings of reading research and the organization of schools, might be the first task for a revised practice guide. A second task might be to evaluate the developmental differences across adolescents at different ages. Interestingly, Baye and colleagues (2019) noted that within grades 6-12, the oldest students (i.e., 11th and 12th graders) have been least studied. As teachers know, 12-year-old early adolescents generally have less sophisticated worldviews and less content knowledge than 18-year-old young adults, which might have significant implications for literacy recommendations. A practice guide might address these and other developmental differences.

\section{Linguistic Diversity}

In addition, the IES practice guide (Kamil et al., 2008) and Baye et al.s (2019) review differ in their treatment of linguistic diversity. Kamil et al. (2008) included only studies with "students whose first language was English" (p. 5). In contrast, many studies included by Baye et al. had substantial proportions of English learners (ELs). In fact, the IES published a separate guide for teaching academic content to ELs in elementary and middle schools (Baker et al., 2014) but not high school. For context, Herrera et al. (2016) made no mention of the inclusion or exclusion of ELs. Their description of the samples in their 33 reviewed studies included only one with significant linguistic diversity (Vaughn et al. 2009). In addition, the EEF guide (Quigley \& Coleman, 2019) makes no mention of ELs, nor does it cite references to studies of linguistically diverse populations. It seems that these documents do not agree about how to treat linguistically diverse students.

Yet, the evidence suggests that linguistic diversity is a crucial feature of schools. The population of U.K. students who are exposed to a language other than English at home and who attend state-funded secondary schools has risen from under 10\% in 2006 to $17 \%$ in 2019 (U.K. Department for Education, 2019). A similar trend is true in the United States. Whereas absolute percentages of ELs reported by the IES is lower in U.S. secondary schools than in primary schools (approximately 7\% of public high school students in fall 2016), that number is growing: The overall number of ELs in U.S. schools grew approximately $18 \%$ between 2000 and 2016 (National Center for Education Statistics, 2019b). Beyond merely those classified as ELs by schools, U.S. Census data show that $22 \%$ of U.S. residents over 5 years old speak a language other than English at home (U.S. Census Bureau, 2018). In sum, although the two practice guides (IES and EEF) offer little attention to linguistic diversity, the substantial and growing presence of multilingual students in U.S. and U.K. schools suggests that a revised practice guide should directly consider how to integrate students' linguistic diversity into everyday instruction.

A revised guide might make EL-specific and ELunspecific recommendations for teaching with linguistic diversity in mind. For example, McCarty, Pappageorge, and Rueda-Alvarez (2018) showed how a high school serving mostly Latinx students, many of whom also spoke Spanish, moved toward a dialogically organized instructional model that capitalized on students' language background and increased participation in advanced literacy coursework. Alternatively, Olson, Matuchniak, Chung, Stumpf, and Farkas's (2016) evaluation of the Pathway project demonstrated that a cognitive strategies approach to apprenticing high school writers into communities of academic writing was powerfully effective for both ELs and their English-only classmates. A practice guide that identifies how linguistic diversity can be leveraged for success and how good literacy instruction supports all adolescent learners across languages would be an asset to educators.

\section{Learning Diversity}

Baye et al. (2019) included only studies in mainstream English classes, whereas Kamil et al. (2008) relied on numerous studies of only students with disabilities. This distinction changes each review's vision of who an adolescent literacy practice guide is really for. Like Baye and colleagues, Herrera et al. (2016) focused on studies for general education populations, including students with disabilities only when they were part of studies of inclusive mainstream classrooms. Considering the most contemporary practice guide, one of the EEF guide's (Quigley \& Coleman, 2019) seven recommendations is to "provide high quality interventions for struggling students" (p. 30), although the section discussing how to do so focuses on interventions for any student with low literacy and offers little guidance for teachers of students with specific learning disabilities, even those with literacy-specific disabilities such as dyslexia. Truly, these documents vary widely in how they address students with disabilities. 
Yet, the reality of students with disabilities in mainstream classrooms is undeniable. Fourteen percent of all U.S. public school students received special education services in the 2017-2018 school year, with approximately $63 \%$ of those students spending $80 \%$ or more of their time in general education classes (National Center for Education Statistics, 2019a). As models of reading intervention expand in U.S. middle and high schools to meet the learning diversity of their students (e.g., Reed, Wexler, \& Vaughn, 2012), a practice guide should ensure that students with disabilities are considered thoroughly.

An updated practice guide's recommendations might consider including examples of practices that benefit students with disabilities in similar fashion to their peers without disabilities, as well as students not diagnosed with disabilities but who may be considered struggling readers. This would both help general education teachers in supporting students with disabilities and offer advice for administrators designing interventions tailored specifically for these students. For example, Swanson, Wanzek, Vaughn, Roberts, and Fall (2015) noted that multiple studies have demonstrated a "meaningful and positive effect for students with disabilities when literacy interventions are administered in the general education social studies classroom" ( $\mathrm{p}$. 439). A practice guide might offer recommendations specifically for students with disabilities by building on Vaughn and Wanzek's (2014) observation that reading interventions for students with disabilities are often insufficiently intensive or are overly focused on low-level tasks. A revised practice guide would serve educators well if it could offer literacy recommendations for both general and special education classrooms.

\section{An Inclusive, Comprehensive Definition}

Based on these documents, it seems that that no consensus exists about who adolescent readers are. Table 1 summarizes the four documents' inclusion perspectives. Despite this lack of consensus, I propose that given the current grade-level structure of U.S. schools and the standards they teach to, and given the presence of ELs and students with disabilities in those schools, a revised practice guide should use a comprehensive definition that bases its recommendations on all studies of students in grades 6-12, including ELs and students with disabilities.

\section{What Is a Reading Program?}

Neither Kamil et al. (2008) nor Baye et al. (2019) explicitly defined reading or reading instruction. Kamil and colleagues used the term literacy in their title and frequently throughout their text, but also qualified this decision by explaining, "while fully understanding that all aspects of literacy are important for success in middle and high school, panel members decided to focus specifically on studies about reading, that is, studies in which reading was a dependent variable" (p. 5). Here, reading was not explicitly defined but was operationalized as a process by which students were measured in their performance on comprehension tests. In this respect, Baye and colleagues' approach was similar: They did not define reading but instead operationalized it through inclusion criteria requiring standardized quantitative outcomes.

This operationalization merits some attention, especially attending to how reading is assessed. For example, one common reading comprehension measure used by the studies in Baye et al's (2019) corpus is the GatesMacGinitie Reading Tests, which do not ask students to integrate meaning across multiple texts, critique meaning, interact with multimodal texts, or read in the context of socially situated practices (i.e., history, science; for more on the theoretical implications of attending to types of contexts and tasks in reading, see Rouet, Britt, \& Durik, 2017). Researchers and practitioners working together might also notice that new comprehension measures can more robustly address such complexities in reading (see, e.g., the Global Integrated Scenario-based Assessment [GISA]; Sabatini, O’Reilly, Halderman, \& Bruce, 2014). Such assessments might better demonstrate the effectiveness of literacy interventions conducted in, for example, biology classrooms (e.g., Goldman et el., 2019). If practice guides and reviews do not directly define reading, it

TABLE 1

Summary of the Inclusion Criteria of Each Document

\begin{tabular}{|llll|}
\hline Document & $\begin{array}{l}\text { Country and grade } \\
\text { levels of students } \\
\text { addressed }\end{array}$ & Linguistic diversity & Learning diversity \\
\hline Kamil et al. (2008) & U.S. grades 4-12 & ELs explicitly excluded & SWD included \\
\hline Herrera, Truckenmiller, and Foorman (2016) & U.S. grades 6-12 & ELs not mentioned & SWD not mentioned \\
\hline Baye, Inns, Lake, and Slavin (2019) & $\begin{array}{l}\text { U.S. grades 6-12 } \\
\text { Quigley and Coleman (2019) }\end{array}$ & ELs included & $\begin{array}{l}\text { SWD included only if in } \\
\text { mainstream classes }\end{array}$ \\
\hline
\end{tabular}

Note. ELs = English learners; SWD = students with disabilities. 
is incumbent upon critical readers to consider the design of the assessments used to measure it.

The lack of a definition of reading also means that these documents all offer different definitions of a reading program. The evidence base for Kamil et al.s (2008) practice guide includes exclusively programs that would be seen as traditional classroom literacy instruction. In contrast, although many of Baye et al's (2019) reviewed studies included many traditional programs, they also included whole-school reform approaches such as the Building Assets Reducing Risks program (Borman et al., 2017), which targeted literacy outcomes indirectly through improving socioemotional learning and teacher-student relationships. Similarly, Herrera and colleagues (2016) reviewed mostly traditional programs directly targeting literacy but also included, for example, a study of the effects of single-sex classrooms on reading outcomes (Belcher, Frey, \& Yankeelov, 2006). Given the breadth of potential practices that might affect literacy outcomes, both directly and indirectly, a revision of the IES practice guide should carefully define what constitutes a literacy program.

What might this definition look like? In their review of trends in literacy research, Frankel and colleagues (2016) proposed a shift from reading to literacy to better account for, among other things, research documenting the situated nature of literacy development in social contexts and academic disciplines; the intertwined relations among oral language, reading, and writing development; and more expansive understandings of multimodal texts. Frankel et al. defined literacy "as the process of using reading, writing, and oral language to extract, construct, integrate, and critique meaning through interaction and involvement with multimodal texts in the context of socially situated practices" (p. 7). A revised practice guide might consider how an expanded definition could include programs focused on constructs beyond reading but which nevertheless have been shown to support reading (writing: e.g., Olson et al., 2016; disciplinary literacy: e.g., Goldman et al., 2019). In fact, the IES practice guide for teaching secondary students to write effectively (Graham et al., 2016) already recommends that teachers should "integrate writing and reading to emphasize key writing features" (p. 31), and many U.S. states' literacy accountability measures (e.g., end-of-course English 1 exams) include both reading and writing tasks. A revised practice guide might more accurately fulfill its title of "adolescent literacy" by conceptualizing literacy programs more broadly and also defining its relation to Graham and colleagues' (2016) IES practice guide for adolescent writing.

\section{What Is Evidence? \\ Experimental Evidence}

Both the Baye team's (2019) synthesis and the IES practice guide (Kamil et al., 2008) start from similar assumptions about high-quality evidence: randomized controlled trials and quasi-experiments with treatment assignment mechanisms known in advance (Campbell \& Stanley, 1963). In fact, Baye et al. used 12 inclusion criteria (discussed in the Method section), and Herrera and colleagues (2016) used the What Works Clearinghouse (2014) version 3.0 protocol, which includes randomassignment designs and those with established baseline equivalence. In contras, the EEF guide (Quigley \& Coleman, 2019) does not define evidence; its brief methodological appendix merely mentions that "the review team conducted searches for the best available international evidence" (p. 37). Whereas the EEF guide's authors abstained from addressing the nature of evidence, the research teams led by Baye, Herrera, and Kamil all prized experimental evidence.

Research has shown how methodological factors of experimental designs can affect outcomes. Scammacca and colleagues (2007) showed that researcher-delivered studies tend to have higher effect sizes than teacherdelivered studies (a finding echoed by de Boer, Donker, \& van der Werf, 2014). In addition, recent research designs have shifted toward teacher-delivered studies, which means that Baye and colleagues (2019) had a substantial corpus of studies meeting this criteria. Although researcher-delivered studies have merit as incubators of innovative instructional design and should continue to be funded as a test bench for future studies, a practice guide should include only studies delivered by grades 6-12 educators.

Deciding whether to include researcher-developed assessments is another consideration. Both de Boer et al. (2014) and Cheung and Slavin (2016) showed that studies with researcher-developed assessments tend to produce higher effect sizes than studies using standardized assessments do. Baye and colleagues' (2019) decision to exclude researcher-developed measures offers direct help to educators and policymakers making instructional decisions using existing assessments. In fact, though, Baye et al. included, against their stated criteria, two studies in which the measures were explicitly developed for the studies (Fancsali et al., 2015; Jaciw, Schellinger, Lin, Zacamy, \& Toby, 2016). This measure, the GISA, was developed in conjunction with the researchers and specifically for the studies of Reading Apprenticeship. However, the reliability and validity of the GISA had already been established elsewhere (for that and an extended discussion of the issue of aligning interventions and outcomes for reading comprehension, see O'Reilly, Weeks, Sabatini, Halderman, \& Steinberg, 2014), so the GISA straddled the line between researcher-developed and standardized. It seems that the issue in defining acceptable evidence for a revised practice guide might not be merely a question of who designed the assessments, but rather answering these two questions: 
1. Have the assessments demonstrated sufficient reliability and validity to recommend widespread use?

2. Is the evidence for a practice corroborated across multiple assessments?

These questions should be asked with a strong skepticism of studies with assessments developed directly for their interventions. As few assessments made by researchers for individual studies will have previously demonstrated extensive reliability or validity, this will be an appropriately high bar. Also notable, Cheung and Slavin (2016) highlighted concerns with studies using treatmentinherent assessments, that is, studies whose experimental groups were taught content or skills not taught in the control groups, essentially a form of teaching to the test. Given these concerns, a preference for standardized measures not developed for specific studies, a requirement that all studies' measures have demonstrated reliability and validity, and a rejection of treatment-inherent designs would be good starting points for a revised practice guide.

In considering how studies' outcome measures are crucial to determining their suitability as evidence for a practice guide, a revised guide might not only reflect existing and familiar accountability measures common in practice (e.g., state tests, Measures of Academic Progress assessments, Gates-MacGinitie Reading Tests) but also translate innovative assessment research showing dimensions of adolescent literacy not yet explored by the research underpinning the 2008 IES practice guide. More well-developed and validated assessments specifically designed for adolescents exist now than in 2008 , such as these examples:

- GISA (O’Reilly et al., 2014), which uses an innovative approach with multiple texts and purposeful scenarios to assess dimensions of comprehension beyond typical single passages with questions

- Reading Inventory and Scholastic Evaluation (Sabatini et al., 2014), a standardized measure specifically designed to assess the profiles of reading difficulties experienced by students in grades $5-10$

- Monster, P.I. (Goodwin et al., 2020), an iPad-based gamified assessment of middle schoolers' language skills, a crucial component of their comprehension

- Core Academic Language Skills assessment (Uccelli et al., 2015) of middle schoolers' academic language

Well-validated assessments are likely to be of value to all of the audiences for a practice guide, including not only teachers but also district- and state-level policymakers. In addition, some of these assessments might help target the skills that underlie reading comprehension, such as the Reading Inventory and Scholastic Evaluation targeting word reading, Monster, P.I. addressing language skills, and the Core Academic Language Skills assessment addressing academic language. As these and other assessments make their way into educational practice, a revised practice guide could advise educators not only on literacy instruction but also on systematic literacy assessment.

Finally, the nature of acceptable evidence should also consider the criteria for positive effects. Per the What Works Clearinghouse guidelines at the time, Kamil et al. (2008) required either a statistically significant effect or a large effect size (>0.25) and included little discussion of comparative effect sizes. Knowing, however, that adolescent literacy effect sizes tend to be much smaller than those in elementary literacy (Hill, Bloom, Black, \& Lipsey, 2008) and that methodological decisions can affect the power to detect statistically significant effects, it makes sense that smaller effect sizes and those that might not reach certain $p$-values are likely practically meaningful for adolescent literacy, especially on standardized measures. In fact, only four of the 69 studies in Baye et al's (2019) corpus had effect sizes above 0.25 , suggesting the difficulty of producing large effect sizes. A revised practice guide would do well to consider the value of effect sizes that might not have reached significance but still represent practical success and improvement over typical instructional practice (Lipsey et al., 2012).

\section{Methodological Lenses}

Educators want to know what works in adolescent literacy, and certainly experimental and quasi-experimental evidence helps answer that question. A revised IES practice guide would likely need to hew to the current What Works Clearinghouse standards to ground its recommendations, and experimental evidence has been prized by most practice guides. If, however, an expanded definition of literacy (Frankel et al., 2016) includes attention to socially situated literacy practices, research through additional methodological lenses on literacy might illustrate not only what works but also how it works and what kinds of relationships and social structures are needed to support changes in literacy instructional practice. These questions might be better answered by relying on design-based or formative experiments, and a revised practice guide might rely on both. For example, whereas disciplinary literacy in history has a growing experimental evidence base (Reisman, 2012), qualitative research has examined the adaptive process of teachers integrating disciplinary literacy into their instruction (Athanases \& de Oliveira, 2014; Dobbs, Ippolito, \& Charner-Laird, 2016). Qualitative research and teachers' implementation stories could provide texture to a practice guide speaking to an educator audience.

\section{Comparing the Evidence Bases}

Inspired by Baye and colleagues' (2019) review, I investigated the IES practice guide's (Kamil et al., 2008) underlying evidence. I wanted to know whether its evidence 
would have met today's standards. To do so, I tracked down the 34 studies that Kamil and colleagues (2008) defined as rigorous designs (randomized controlled trials and quasi-experiments as defined earlier, which included master's theses, dissertations, and white papers), and I coded whether each study would meet each or all of the 12 inclusion criteria established by Baye et al. To verify my coding, a research assistant double-coded $50 \%$ of the studies across all 12 criteria, relying only on evidence directly presented in the reports. Initial agreement was above 95\%, and we agreed on a final set of results, which I share here. As a check against whether my results were too author specific, I also examined whether any of the 34 studies from Kamil et al.s practice guide was cited in the two other contemporary documents: Herrera and colleagues' (2016) systematic review and the EEF practice guide (Quigley \& Coleman, 2019). The results are presented in Tables 2-4.

\section{Who Were the Underlying Studies' Adolescents?}

My findings are organized in three tables according to the 12 criteria set out by Baye et al. (2019). Table 2 shows the two criteria that defined adolescent study participants.
Criteria 1 and 2 show that a substantial proportion of studies in the IES practice guide were conducted in fourth or fifth grade and in special education settings: $44 \%$ for each, although those were not necessarily the same studies. In fact, of the IES practice guide's 34 studies, only one took place in a typically developing high school setting with an outcome measure of reading (Barron \& Melnick, 1973 , a white paper studying vocabulary acquisition in a biology class). The evidence base underpinning Kamil et al's (2008) practice guide clearly skewed toward younger and special education populations, whereas the studies that Baye et al. (2019) reviewed were markedly older and more general education populations.

\section{How Did the Underlying Studies Define Reading?}

When comparing how Kamil et al.s (2008) practice guide and Baye et al.s (2019) research synthesis defined reading on the four criteria shown in Table 3, strong similarities are apparent. Criteria 4-6 show nearly complete agreement. In addition, for criterion 6, although Kamil et al. explicitly focused on quantitative measures of reading, they included two studies whose only

\section{TABLE 2}

\section{Who Were the Adolescents Studied?}

\begin{tabular}{|llc|}
\hline $\begin{array}{l}\text { Criterion } \\
\text { number }\end{array}$ & Baye et al.'s (2019) criterion & $\begin{array}{c}\text { Number of Kamil et al.'s } \\
\text { (2008) 34 reviewed studies } \\
\text { meeting the criterion }\end{array}$ \\
\hline 1 & $\begin{array}{l}\text { Studies evaluated reading programs for middle and high schools } \\
\text { (grades 6-12). }\end{array}$ & 19 \\
\hline 2 & $\begin{array}{l}\text { Students who qualified for special education services but attended } \\
\text { mainstream English or reading classes were included. }\end{array}$ & 56 \\
\hline
\end{tabular}

\section{TABLE 3}

What Experimental Designs About Reading Were Included?

\begin{tabular}{|c|c|c|c|}
\hline $\begin{array}{l}\text { Criterion } \\
\text { number }\end{array}$ & Baye et al.'s (2019) criterion & $\begin{array}{l}\text { Number of Kamil et al.'s } \\
(2008) 34 \text { reviewed studies } \\
\text { meeting the criterion }\end{array}$ & Percentage \\
\hline 3 & $\begin{array}{l}\text { Studies could have taken place in any country, but the report had } \\
\text { to be available in English. In practice, all included programs took } \\
\text { place in the United States or the United Kingdom. }\end{array}$ & 34 & 100 \\
\hline 4 & $\begin{array}{l}\text { Studies compared students with a given reading program with } \\
\text { those taught in an alternative or business-as-usual control group. }\end{array}$ & 32 & 94 \\
\hline 5 & $\begin{array}{l}\text { Studies used random assignment to experimental and control } \\
\text { conditions, or quasi-experimental methods in which treatment } \\
\text { assignments were specified in advance. }\end{array}$ & 32 & 94 \\
\hline 6 & $\begin{array}{l}\text { Studies' dependent measures had to be quantitative measures of } \\
\text { reading performance. }\end{array}$ & 32 & 94 \\
\hline 7 & $\begin{array}{l}\text { Studies had to be carried out after } 1990 \text {, but for technological } \\
\text { approaches, Baye et al. used a start date of } 2000 \text { because of the } \\
\text { significant advances in technology since then. }\end{array}$ & 24 & 71 \\
\hline
\end{tabular}


TABLE 4

What Methodological Factors Changed?

\begin{tabular}{|c|c|c|c|}
\hline $\begin{array}{l}\text { Criterion } \\
\text { number }\end{array}$ & Baye et al.'s (2019) criterion & $\begin{array}{l}\text { Number of Kamil et al.'s (2008) } \\
34 \text { reviewed studies meeting } \\
\text { the criterion }\end{array}$ & Percentage \\
\hline \multirow[t]{2}{*}{8} & \multirow{2}{*}{$\begin{array}{l}\text { Studies had to provide pretest data. Those with experimental- } \\
\text { control differences equivalent to an effect size of } 0.25 \text { or } \\
\text { more on pretests were excluded. Pretest equivalence had } \\
\text { to be acceptable both initially and based on pretests for the } \\
\text { final sample, after attrition. Differential attrition from pre- to } \\
\text { posttest had to be less than } 15 \% \text {. }\end{array}$} & Pretests: 26 & 77 \\
\hline & & Attrition: 12 & 35 \\
\hline 9 & $\begin{array}{l}\text { Treatments had to be delivered by ordinary teachers, not } \\
\text { by researchers, because effect sizes are inflated when } \\
\text { researchers deliver the treatment (Scammacca et al., 2007). }\end{array}$ & 18 & 53 \\
\hline 10 & $\begin{array}{l}\text { Assessments made by developers or researchers were } \\
\text { excluded, as such measures have been found to greatly } \\
\text { overstate program impacts. }\end{array}$ & 13 & 38 \\
\hline 11 & $\begin{array}{l}\text { Studies had to have a minimum duration of } 12 \text { weeks to make } \\
\text { it more likely that effective programs could be replicated over } \\
\text { extended periods. }\end{array}$ & 8 & 24 \\
\hline 12 & $\begin{array}{l}\text { Studies had to have at least two teachers and } 30 \text { students in } \\
\text { each treatment group. }\end{array}$ & 14 & 41 \\
\hline
\end{tabular}

outcome measures were of writing (Applebee, Langer, Nystrand, \& Gamoran, 2003; Reznitskaya et al., 2001). Examining criterion 7 in Table 3 through a historical lens, over two thirds of Kamil et al's studies were published between 1990 and 2008, which were within Baye et al.s cutoff dates of 1990-2019 and thus chronologically eligible. However, Baye et al., who assessed over 15,000 potential studies in their literature search, found only two includable studies from before 2010 (both reported by Stevens \& Durkin, 1992). This suggests that the evidence base turned over nearly completely in only a decade.

\section{What Were the Underlying Studies' Methodological Differences?}

Table 4 shows that many studies cited by Kamil et al. (2008) did not pass the specific methodological criteria set out by Baye et al. (2019). Criteria 9-12 shows that a substantial proportion of the studies were delivered by researchers, used researcher-designed assessments, lasted for shorter durations, and had small sample sizes. In fact, the average sample size of the studies in Kamil et al. was 91 students, but for Baye et al., the average was 2,059 students-over 22 times larger.

Finally, no studies cited by Kamil et al. (2008) met all of the inclusion criteria of Baye et al. (2019). One study, though, would have met all of them (Nelson \& Stage, 2007), but it was conducted with third and fifth graders and so was excluded only on criterion 1 . The other 33 studies would all have been excluded by two or more criteria. It is also worth mentioning that none of the 34 studies included in Kamil et al.s practice guide were included in either the 33 studies in Herrera and colleagues' (2016) systematic review or any of the 66 works cited in the EEF practice guide (Quigley \& Coleman, 2019).

\section{What Do These Findings Mean?}

These findings demonstrate that the evidence base on adolescent reading has shifted drastically in just a decade. Although based on similar research designs and conceptualizing reading in similar fashions (cf. Table 2), the studies that constitute the best experimental evidence today are far larger and far more methodologically rigorous (cf. Table 3). In fact, only a single study of the 34 cited in Kamil et al.s (2008) practice guide met the methodological criteria for Baye et al's (2019) synthesis, and none were included in two other contemporary documents (Herrera et al., 2016; Quigley \& Coleman, 2019).

Developmentally, it is clear that by including fourth and fifth graders, Kamil et al.s (2008) practice guide included many more studies than if Kamil et al. had they set their lower age boundary to sixth grade, potentially basing their recommendations on younger readers who would not be considered adolescent by many U.S. middle schools or by the Common Core. This is not to fault those authors; they were working with the best available evidence then. It is striking, however, that the recommendations for widespread adolescent literacy practice from one of the most authoritative voices in U.S. education (i.e., the IES) relied on an evidence base that, at the time, included only a single 
study from mainstream high school classes and excluded any studies with ELs (or even bilingual students). Conversely, only a decade later and despite much more rigorous inclusion criteria, Baye et al. (2019) found 30 studies conducted in mainstream high school classes and numerous studies featuring linguistically diverse students.

It is noteworthy that the IES practice guide's evidence base skewed strongly toward younger students in 2008 . Although Kamil et al.s (2008) assertion that students in fourth grade and up tend to have achieved proficiency in word identification and are thus more similar to high school students than early elementary students is consistent with current research (e.g., Foorman et al., 2018), differences may still exist between fourth graders and high school students that would be consequential for reading instruction. Sabatini, Wang, and O'Reilly (2019) found that as many as $17 \%$ of U.S. fourth graders have inadequate word identification skills, suggesting that a decision to bound an adolescent literacy practice guide at sixth grade should also consider that there may be a significant number of students who have not mastered word identification. In addition, given the current grade structure of the majority of U.S. middle schools beginning in sixth grade (National Middle School Association, 2003), such a practice guide might best serve the developmental and social concerns for middle and high school students that are consequential for literacy instruction in the upper grades.

\section{Implications for Practice Guides}

The purpose of this commentary is to call for the revision of the IES practice guide to reflect a more inclusive definition of adolescent literacy and incorporate the expanded breadth and rigor of the research of the last decade. Perhaps a more inclusive definition will challenge future practice guide writers, but they will also have an expanded evidence base available to them. The structure for a revised guide might take many forms, one way a revision might address inclusion is by making a set of general recommendations and also including, for each recommendation, evidence-based instructional adaptations for ELs and students with disabilities.

Making these recommendations will be difficult. It may be that insufficient research exists to provide evidencebased instructional adaptations for all recommendations and all subgroups of students, and different student populations may have different amounts and types of evidence (i.e., more single-subject designs for special education). Still, acknowledging the limitations of the existing research and basing the strength of the recommendations on different amounts and kinds of empirical evidence is also a fundamental task for the authors of a revised practice guide. In fact, the Every Student Succeeds Act (2015) invites educators to consider studies' sample characteristics before determining whether those studies constitute acceptable evidence for particular settings and students (U.S. Department of Education, 2016). A revised practice guide would help educators do so, truly translating research into practices adaptable to the diversity and complexity of adolescent literacy.

To explore how a new practice guide might extend the existing version, I review here each of the five recommendations in Kamil et al.s (2008) practice guide in light of more recent findings. Although a revised practice guide would likely reexamine the structure and number of recommendations based on the expanded research (e.g., the EEF guide has seven), I hew to the existing recommendations to most directly show how, in only a decade, meaningful research findings have reshaped adolescent literacy recommendations. Certainly, this is not an exhaustive list of the implications of new research for a future practice guide, as that list would be the work of a new committee, but this is a starting point.

\section{Kamil et al.'s (2008) Five Recommendations \\ Provide Explicit Vocabulary Instruction}

The first recommendation of Kamil et al. (2008) was to provide direct and explicit vocabulary instruction, even though the authors noted that "only a small number of the studies on explicit vocabulary instruction...found meaningful increases in students' reading comprehension" ( $p$. 13). In fact, of the four studies that Baye et al. (2019) categorized as vocabulary focused, none found significant effects on comprehension, and Wright and Cervetti's (2017) RRQ review of 36 vocabulary interventions' impact on comprehension found "very limited evidence that direct teaching of word meanings, even long-term, multifaceted interventions of large numbers of words, can improve generalized comprehension" (p. 203). Whereas this work questions the assumption that direct vocabulary instruction improves comprehension, it may also be weaknesses in prior instructional approaches to vocabulary. For example, McKeown, Crosson, Moore, and Beck's (2018) Robust Academic Vocabulary Encounters intervention included attention to polysemy and morphology, neither of which were included in Kamil et al.s (2008) recommendations, and also found improved comprehension outcomes. Similarly, Jones and colleagues' (2019) evaluation of the Word Generation academic vocabulary intervention in high-poverty schools found notable effects on both proximal measures of academic vocabulary and smaller effects on comprehension. These recent results suggest that the last decade of vocabulary research has much to add to a new practice guide. 


\section{Provide Direct and Explicit Comprehension Strategy Instruction}

This second recommendation is interesting because Baye et al. (2019) specifically cited Kamil et al. (2008) to explain the importance of strategy instruction as an underlying principle in many programs. Baye et al. also noted that of their 69 included studies, "all qualifying programs in this review incorporated metacognitive strategies to a significant degree" (p. 139), indicating that Kamil et al's recommendation may have been more widely adopted now than 10 years ago (although to what degree is unclear). A revised practice guide, then, might better serve practitioners by offering more specific recommendations. What might the last decade of research on comprehension strategies have to offer educators?

\section{Provide Opportunities for Extended Discussion of Text Meaning and Interpretation}

Kamil et al. (2008) specified that this third recommendation was only supported by a moderate level of evidence (the first two were considered strong). Interestingly, discussion was not a stand-alone category in Baye et al's (2019) classification of reading programs. However, programs across several of their categories, including small-group tutoring, whole-school organizational approaches, writing-focused approaches, and group/personalization rotation approaches, all mention discussion as an important program component. Therefore, the contemporary research base affirms and extends the value of discussion, suggesting that the evidence level may be more than moderate for this practice. In fact, an updated practice guide might rely on new research (e.g., Murphy et al., 2018) to help teachers learn how to conduct discussions to maximize literacy growth.

\section{Increase Student Motivation and Engagement in Literacy Learning}

As with the third recommendation, Kamil et al. (2008) judged the evidence for this fourth recommendation to be moderate. Interestingly, Baye et al. (2019) found that "programs with positive outcomes tended to emphasize student motivation, student-to-student and studentto-teacher relationships, and socioemotional learning (Guthrie, 2015)" (p. 156). These recommendations are similar to those in Kamil et al. but particularly emphasize relationship building and socioemotional dimensions of learning, neither of which was explicitly prioritized by Kamil et al. Although few would argue against a focus on student motivation and engagement, an updated practice guide for middle and high school teachers might link motivation and engagement to the social and emotional lives of adolescents and potentially differentiate these recommendations for younger and older adolescents.

\section{Make Available Intensive and Individualized Interventions for Struggling Readers That Can Be Provided by Trained Specialists}

Although Kamil et al. (2008) found the evidence for this practice to be strong, it is unclear just how they were conceptualizing individualized. Studies testing individualization should assign students not to one standard treatment or control but rather to individualized or nonindividualized instruction (for an elementary-age example, see Connor, Morrison, Fishman, Schatschneider, \& Underwood, 2007). None of the studies in Kamil et al. did this. This is not to say that individualized interventions are not effective for struggling adolescent readers, only that Kamil et al's evidence base did not permit this conclusion in 2008. Fortunately, Baye et al's (2019) improved research base offered better evidence. They documented the effectiveness of tutoring programs and personalization approaches, both on their own and in conjunction with group activities. Conversely, Baye et al. found no positive effects for programs of intensive nonindividualized group approaches designed to catch up students on decoding and word identification skills typically learned before adolescence, although many students have not (Sabatini et al., 2019). Overall, these findings suggest that an updated practice guide might address how interventions (including those targeting word identification) can be individualized to serve struggling adolescent readers.

\section{Technology, Disciplinary Literacy, and Writing}

Beyond their five recommendations, Kamil et al. (2008) addressed three other topics. They noted that at that time, there was insufficient research to make any claims about the use of technology in reading instruction. Interestingly, Baye et al's (2019) review examined technology as a crosscutting factor among their 69-study corpus by identifying the 23 programs that included technology in some manner (with varying intensity and types of technology use) and comparing them with the 46 programs that did not use technology at all, finding no consistent benefit to programs incorporating technology. Thus, despite strong growth in the use of technology in reading instruction in the last decade and enormous advances in software design and programming, Kamil et al.s recommendation rings true today: Technology can be part of good adolescent reading instruction, but it appears to carry no inherent benefit visible across programs. Still, Baye et al's assessment only addressed standardized reading outcomes, and remembering Frankel and colleagues' (2016) expanded definition of literacy, a practice guide might also address how, in the last decade, literacy research has explored the nature of reading in digital environments (Coiro, 2020), multimodal text 
composition (Smith, Pacheco, \& Khorosheva, 2020), and the social and collaborative features of new literacies (Leu, Kinzer, Coiro, Castek, \& Henry, 2017).

Beyond technology, Kamil et al. (2008) noted the emergence of research on disciplinary literacy but asserted that "the formal evidence base for these methods is not yet sufficiently developed" (p. 8). That has since changed. Now, reading programs prioritizing disciplinary content have been experimentally tested (see, e.g., Project READi: Goldman et al., 2019; Reading Like a Historian: Reisman, 2012; Reading Apprenticeship: Greenleaf et al., 2011). An updated practice guide for adolescent literacy should explicitly address the implications of this growing research base.

Similarly, although Kamil et al. (2008) did not address links between reading and writing, meta-analyses have demonstrated positive effects on comprehension from both writing interventions alone (Graham \& Hebert, 2011) and programs balancing reading and writing instruction (Graham et al., 2018). Although writing is occasionally mentioned in Kamil et al's recommendations, and in fact a stand-alone IES practice guide addresses how to improve secondary writing (Graham et al., 2016), sufficient research about the intersections of reading and writing for adolescents now exists and should inform a revised practice guide.

\section{Conclusions and Future Directions}

Synthesizing the complex findings of education research into recommendations for practice is no small task. In fact, the International Reading Association's (2012; now the International Literacy Association) position statement on adolescent literacy, which was the work of the association's Adolescent Literacy Committees and Adolescent Literacy Task Force, declared, "Never before have we had so much knowledge about adolescent literacy" (p. 3). Given the breadth of new evidence in 2020, that declaration should be sounded even more vigorously. Because the investment in and demand for evidence-based literacy practices shows little sign of abating, both the IES and the International Literacy Association might consider establishing standing committees that monitor research on adolescent literacy and update practice recommendations. These committees would be well positioned to expand on the historical strengths of literacy research and incorporate current findings.

Because these committees will work at the leading edge of research and must consider the complexities of adolescent literacy and the nuances of research design, some disagreement about definitions and inclusion criteria is inevitable. Honoring the diversity and heterogeneity of adolescents' literacy learning is daunting. Still, this cannot absolve researchers from the necessary task of making practice recommendations and updating those from over a decade ago. The composition of a standing committee would benefit from multiple methodological and content perspectives, expertise in linguistic and learning diversity, and the participation of grades 6-12 teachers.

Such a standing committee might make use of not only more recent reviews, such as Baye and colleagues (2019) and Herrera and colleagues (2016), but also contemporary online databases of research reviews. These databases include the What Works Clearinghouse (https://ies. ed.gov/ncee/wwc/) and the Evidence for ESSA website (https://www.evidenceforessa.org/) produced by the Center for Research and Reform in Education at Johns Hopkins University. In addition, the EEF is creating a similar database expected to be completed by 2021 . These databases, although likely insufficient on their own, would help a standing committee keep pace with the explosive growth of research. Such a model is not unlike those used in medicine. Just as the American Academy of Pediatrics, for example, publishes regularly updated recommendations to guide parents' decisions about screen use, child nutrition, and car seats, so too might our flagship educational organizations provide a similar service to teachers. Ultimately, educators equipped with an up-to-date adolescent literacy practice guide will be stronger partners in helping adolescents become more literate world citizens.

\section{NOTES}

No data were collected from any study participants for this article. I would like to thank the following people: Marcia Barhnart, Roger Howard, and Rachel Daniels, as well as my colleagues at the Ohio Department of Education, for inspiring this work, and Liz Litzinger for her coding assistance.

\section{REFERENCES}

Applebee, A.N., Langer, J.A., Nystrand, M., \& Gamoran, A. (2003). Discussion-based approaches to developing understanding: Classroom instruction and student performance in middle and high school English. American Educational Research Journal, 40(3), 685-730. https://doi.org/10.3102/00028312040003685

Athanases, S.Z., \& de Oliveira, L.C. (2014). Scaffolding versus routine support for Latina/o youth in an urban school: Tensions in building toward disciplinary literacy. Journal of Literacy Research, 46(2), 263299. https://doi.org/10.1177/1086296X14535328

Baker, S., Lesaux, N., Jayanthi, M., Dimino, J., Proctor, C.P., Morris, J., ... Newman-Gonchar, R. (2014). Teaching academic content and literacy to English learners in elementary and middle school (NCEE 2014-4012). Washington, DC: National Center for Education Evaluation and Regional Assistance, Institute of Education Sciences, U.S. Department of Education.

Barron, R.F., \& Melnick, R. (1973). The effects of discussion upon learning vocabulary meanings and relationships in tenth grade biology. In H.L. Herber \& R.F. Barron (Eds.), Research in reading in the content areas, a second year report (pp. 46-52). Syracuse, NY: Reading and Language Arts Center, Syracuse University.

Baye, A., Inns, A., Lake, C., \& Slavin, R.E. (2019). A synthesis of quantitative research on reading programs for secondary students. Reading Research Quarterly, 54(2), 133-166. https://doi.org/10.1002/rrq.229

Belcher, C., Frey, A., \& Yankeelov, P. (2006). The effects of single-sex classrooms on classroom environment, self-esteem, and standardized test scores. School Social Work Journal, 31(1), 61-75. 
Boardman, A.G., Boelé, A.L., \& Klingner, J.K. (2018). Strategy instruction shifts teacher and student interactions during text-based discussions. Reading Research Quarterly, 53(2), 175-195. https:/doi.org/ 10.1002/rrq.191

Borman, T., Bos, J., O’Brien, B., Park, S., Liu, F., Corsello, M., \& Jerabek, A. (2017). The BARR program: Impacting social emotional skills and academic achievement of 9th grade students in 6 high schools. Washington, DC: American Institutes for Research.

Campbell, D.T., \& Stanley, J.C. (1963). Experimental and quasiexperimental designs for research. Chicago, IL: Rand McNally.

Cheung, A.C., \& Slavin, R.E. (2016). How methodological features affect effect sizes in education. Educational Researcher, 45(5), 283-292. https://doi.org/10.3102/0013189X16656615

Coiro, J. (2020). Toward a multifaceted heuristic of digital reading to inform assessment, research, practice, and policy. Reading Research Quarterly. Advance online publication. https://doi.org/10.1002/rrq. 302

Connor, C.M., Morrison, F.J., Fishman, B.J., Schatschneider, C., \& Underwood, P. (2007). Algorithm-guided individualized reading instruction. Science, 315(5811), 464-465. https://doi.org/10.1126/ science. 1134513

de Boer, H., Donker, A.S., \& van der Werf, M.P. (2014). Effects of the attributes of educational interventions on students' academic performance: A meta-analysis. Review of Educational Research, 84(4), 509-545. https://doi.org/10.3102/0034654314540006

Dobbs, C.L., Ippolito, J., \& Charner-Laird, M. (2016). Layering intermediate and disciplinary literacy work: Lessons learned from a secondary social studies teacher team. Journal of Adolescent \& Adult Literacy, 60(2), 131-139. https://doi.org/10.1002/jaal.547

Edmonds, M.S., Vaughn, S., Wexler, J., Reutebuch, C., Cable, A., Tackett, K.K., \& Schnakenberg, J.W. (2009). A synthesis of reading interventions and effects on reading comprehension outcomes for older struggling readers. Review of Educational Research, 79(1), 262-300. https://doi.org/10.3102/0034654308325998

Every Student Succeeds Act, 20 U.S.C. $\$ 6301$ (2015). https://www. congress.gov/114/plaws/publ95/PLAW-114publ95.pdf

Fancsali, C., Abe, Y., Pyatigorsky, M., Ortiz, L., Chan, V., Saltares, E., ... Jaciw, A. (2015). The impact of the Reading Apprenticeship Improving Secondary Education (RAISE) project on academic literacy in high school: A report of a randomized experiment in Pennsylvania and California schools. Palo Alto, CA: Empirical Education.

Foorman, B.R., Petscher, Y., \& Herrera, S. (2018). Unique and common effects of decoding and language factors in predicting reading comprehension in grades 1-10. Learning and Individual Differences, 63, 12-23. https://doi.org/10.1016/j.lindif.2018.02.011

Frankel, K.K., Becker, B.L.C., Rowe, M.W., \& Pearson, P.D. (2016). From "what is reading?" to what is literacy? Journal of Education, 196(3), 7-17. https://doi.org/10.1177/002205741619600303

García, J.R., \& Cain, K. (2014). Decoding and reading comprehension: A meta-analysis to identify which reader and assessment characteristics influence the strength of the relationship in English. Review of Educational Research, 84(1), 74-111. https://doi.org/10.3102/00346 54313499616

Goldman, S.R., Greenleaf, C., Yukhymenko-Lescroart, M., Brown, W., Ko, M.-L.M., Emig, J.M., ... Britt, M.A. (2019). Explanatory modeling in science through text-based investigation: Testing the efficacy of the Project READI intervention approach. American Educational Research Journal, 56(4), 1148-1216. https://doi.org/10.3102/00028 31219831041

Goodwin, A.P., Petscher, Y., Jones, S., McFadden, S., Reynolds, D., \& Lantos, T. (2020). The monster in the classroom: Assessing language to inform instruction. The Reading Teacher, 73(5), 603-616. https:// doi.org/10.1002/trtr.1870
Gough, P.B., \& Tunmer, W.E. (1986). Decoding, reading, and reading disability. Remedial and Special Education, 7(1), 6-10. https://doi. org/10.1177/074193258600700104

Graham, S., Bruch, J., Fitzgerald, J., Friedrich, L.D., Furgeson, J., Greene, K., ... Smither Wulsin, C. (2016). Teaching secondary students to write effectively (NCEE 2017-4002). Washington, DC: National Center for Education Evaluation and Regional Assistance, Institute of Education Sciences, U.S. Department of Education.

Graham, S., \& Hebert, M. (2011). Writing to read: A meta-analysis of the impact of writing and writing instruction on reading. Harvard Educational Review, 81(4), 710-744 https://doi.org/10.17763/haer. 81.4.t2k0m13756113566

Graham, S., Liu, X., Aitken, A., Ng, C., Bartlett, B., Harris, K.R., \& Holzapfel, J. (2018). Effectiveness of literacy programs balancing reading and writing instruction: A meta-analysis. Reading Research Quarterly, 53(3), 279-304. https://doi.org/10.1002/rrq.194

Greenleaf, C.L., Litman, C., Hanson, T.L., Rosen, R., Boscardin, C.K., Herman, J., ... Jones, B. (2011). Integrating literacy and science in biology: Teaching and learning impacts of Reading Apprenticeship professional development. American Educational Research Journal, 48(3), 647-717. https://doi.org/10.3102/0002831210384839

Herrera, S., Truckenmiller, A.J., \& Foorman, B.R. (2016). Summary of 20 years of research on the effectiveness of adolescent literacy programs and practices (REL 2016-178). Washington, DC: Regional Educational Laboratory Southeast, National Center for Education Evaluation and Regional Assistance, Institute of Education Sciences, U.S. Department of Education.

Hill, C.J., Bloom, H.S., Black, A.R., \& Lipsey, M.W. (2008). Empirical benchmarks for interpreting effect sizes in research. Child Development Perspectives, 2(3), 172-177. https://doi.org/10.1111/j. 1750-8606.2008.00061.x

Imbrenda, J.P. (2018). Developing academic literacy: Breakthroughs and barriers in a college-access intervention. Research in the Teaching of English, 52(3), 317-341.

International Reading Association. (2012). Adolescent literacy [Position statement]. Retrieved from https://www.literacyworldwide.org/ docs/default-source/where-we-stand/adolescent-literacy-positionstatement.pdf?sfvrsn $=8$

Jaciw, A.P., Schellinger, A.M., Lin, L., Zacamy, J., \& Toby, M. (2016). Effectiveness of internet-based Reading Apprenticeship Improving Science Education (iRAISE): A report of a randomized experiment in Michigan and Pennsylvania. Palo Alto, CA: Empirical Education.

Jones, S.M., LaRusso, M., Kim, J., Kim, H.Y., Selman, R., Uccelli, P., ... Snow, C. (2019). Experimental effects of Word Generation on vocabulary, academic language, perspective taking, and reading comprehension in high-poverty schools. Journal of Research on Educational Effectiveness, 12(3), 448-483. https://doi.org/10.1080/19345747. 2019.1615155

Kamil, M.L., Borman, G.D., Dole, J., Kral, C.C., Salinger, T., \& Torgesen, J. (2008). Improving adolescent literacy: Effective classroom and intervention practices: A practice guide (NCEE 2008-4027). Washington, DC: National Center for Education Evaluation and Regional Assistance, Institute of Education Sciences, U.S. Department of Education.

Kim, J.S., Hemphill, L., Troyer, M., Thomson, J.M., Jones, S.M., LaRusso, M.D., \& Donovan, S. (2017). Engaging struggling adolescent readers to improve reading skills. Reading Research Quarterly, 52(3), 357382. https://doi.org/10.1002/rrq.171

Leu, D.J., Kinzer, C.K., Coiro, J., Castek, J., \& Henry, L.A. (2017). New literacies: A dual-level theory of the changing nature of literacy, instruction, and assessment. Journal of Education, 197(2), 1-18. https://doi.org/10.1177/002205741719700202

Lipsey, M.W., Puzio, K., Yun, C., Hebert, M.A., Steinka-Fry, K., Cole, M.W., ... Busick, M.D. (2012). Translating the statistical representation of the effects of education interventions into more readily 
interpretable forms (NCSER 2013-3000). Washington, DC: National Center for Special Education Research, Institute of Education Sciences, U.S. Department of Education.

McCarty, R., Pappageorge, T., \& Rueda-Alvarez, C. (2019). Resisting the "más o menos" mindset: Design-based research to boost Latinx success in advanced coursework through dialogically organized instruction. In M. Nachowitz \& K.C. Wilcox (Eds.), High literacy in secondary English language arts: Bridging the gap to college and career (pp. 185-210). Lanham, MD: Lexington.

McKeown, M.G., Crosson, A.C., Moore, D.W., \& Beck, I.L. (2018). Word knowledge and comprehension effects of an academic vocabulary intervention for middle school students. American Educational Research Journal, 55(3), 572-616. https://doi.org/10.3102/0002831 217744181

Murphy, P.K., Greene, J.A., Firetto, C.M., Hendrick, B.D., Li, M., Montalbano, C., \& Wei, L. (2018). Quality Talk: Developing students' discourse to promote high-level comprehension. American Educational Research Journal, 55(5), 1113-1160. https://doi.org/10.3102/ 0002831218771303

National Center for Education Statistics. (2019a). Children and youth with disabilities. Retrieved from https://nces.ed.gov/programs/coe/indicator_ cgg.asp

National Center for Education Statistics. (2019b). English language learners in public schools. Retrieved from https://nces.ed.gov/progr ams/coe/indicator_cgf.asp

National Governors Association Center for Best Practices \& Council of Chief State School Officers. (2010). Common Core State Standards for English language arts and literacy in history/social studies, science, and technical subjects. Washington, DC: Authors.

National Middle School Association. (2003). This we believe: Successful schools for young adolescents. Westerville, $\mathrm{OH}$ : Author.

Nelson, J.R., \& Stage, S.A. (2007). Fostering the development of vocabulary knowledge and reading comprehension though contextuallybased multiple meaning vocabulary instruction. Education and Treatment of Children, 30(1), 1-22. https://doi.org/10.1353/etc.2007. 0003

Northrop, L., \& Kelly, S. (2019). Who gets to read what? Tracking, instructional practices, and text complexity for middle school struggling readers. Reading Research Quarterly, 54(3), 339-361. https:// doi.org/10.1002/rrq.237

Olson, C.B., Matuchniak, T., Chung, H.Q., Stumpf, R., \& Farkas, G. (2016). Reducing achievement gaps in academic writing for Latinos and English learners in grades 7-12. Journal of Educational Psychology, 109(1), 1-21. https://doi.org/10.1037/edu0000095

O’Reilly, T., Weeks, J., Sabatini, J., Halderman, L., \& Steinberg, J. (2014). Designing reading comprehension assessments for reading interventions: How a theoretically motivated assessment can serve as an outcome measure. Educational Psychology Review, 26(3), 403-424. https://doi.org/10.1007/s10648-014-9269-z

Proctor, C.P., Silverman, R.D., Harring, J.R., Jones, R.L., \& Hartranft, A.M. (2020). Teaching bilingual learners: Effects of a language-based reading intervention on academic language and reading comprehension in grades 4 and 5. Reading Research Quarterly, 55(1), 95-122. https://doi.org/10.1002/rrq.258

Quigley, A., \& Coleman, R. (2019). Improving literacy in secondary schools: Guidance report. London, UK: Education Endowment Foundation.

Reed, D.K., Wexler, J., \& Vaughn, S. (2012). RTI for reading at the secondary level: Recommended literacy practices and remaining questions. New York, NY: Guilford.

Reisman, A. (2012). Reading like a historian: A document-based history curriculum intervention in urban high schools. Cognition and Instruction, 30(1), 86-112. https://doi.org/10.1080/07370008.2011. 634081

Reznitskaya, A., Anderson, R.C., McNurlen, B., Nguyen-Jahiel, K., Archodidou, A., \& Kim, S. (2001). Influence of oral discussion on written argument. Discourse Processes, 32(2/3), 155-175. https://doi. org/10.1080/0163853X.2001.9651596

Rouet, J.-F., Britt, M.A., \& Durik, A.M. (2017). RESOLV: Readers' representation of reading contexts and tasks. Educational Psychologist, 52(3), 200-215. https://doi.org/10.1080/00461520.2017.1329015

Sabatini, J.P., O'Reilly, T., Halderman, L.K., \& Bruce, K. (2014). Integrating scenario-based and component reading skill measures to understand the reading behavior of struggling readers. Learning Disabilities Research \& Practice, 29(1), 36-43. https://doi.org/10. 1111/ldrp. 12028

Sabatini, J., Wang, Z., \& O’Reilly, T. (2019). Relating reading comprehension to oral reading performance in the NAEP fourth-grade special study of oral reading. Reading Research Quarterly, 54(2), 253-271. https://doi.org/10.1002/rrq.226

Scammacca, N., Roberts, G., Vaughn, S., Edmonds, M., Wexler, J., Reutebuch, C.K., \& Torgesen, J.K. (2007). Interventions for adolescent struggling readers: A meta-analysis with implications for practice. Portsmouth, NH: Center on Instruction, RMC Research.

Slavin, R.E., Cheung, A., Groff, C., \& Lake, C. (2008). Effective reading programs for middle and high schools: A best-evidence synthesis. Reading Research Quarterly, 43(3), 290-322. https://doi.org/10.1598/ RRQ.43.3.4

Smith, B.E., Pacheco, M.B., \& Khorosheva, M. (2020). Emergent bilingual students and digital multimodal composition: A systematic review of research in secondary classrooms. Reading Research Quarterly. Advance online publication. https://doi.org/10.1002/ rrq. 298

Stevens, R.J., \& Durkin, S. (1992). Using student team reading and student team writing in middle schools: Two evaluations (Report No. 36). Baltimore, MD: Center for Research on Effective Schooling for Disadvantaged Students, Johns Hopkins University.

Swanson, E., Wanzek, J., Vaughn, S., Roberts, G., \& Fall, A.M. (2015). Improving reading comprehension and social studies knowledge among middle school students with disabilities. Exceptional Children, 81(4), 426-442. https://doi.org/10.1177/0014402914563704

Uccelli, P., Barr, C.D., Dobbs, C.L., Phillips Galloway, E., Meneses, A., \& Sánchez, E. (2015). Core academic language skills: An expanded operational construct and a novel instrument to chart schoolrelevant language proficiency in preadolescent and adolescent learners. Applied Psycholinguistics, 36(5), 1077-1109. https://doi.org/10.1017/ S014271641400006X

U.K. Department for Education. (2019). Schools, pupils and their characteristics: January 2019. Retrieved from https://www.gov.uk/gover nment/statistics/schools-pupils-and-their-characteristics-january-2019

UNESCO Institute for Statistics. (2011). International Standard Classification of Education: ISCED 2011. Montreal, QC, Canada: Author.

U.S. Census Bureau. (2018). American Community Survey 1-year estimates. Retrieved from http://data.census.gov

U.S. Department of Education. (2016). Non-regulatory guidance: Using evidence to strengthen education investments. Retrieved from https:// www2.ed.gov/policy/elsec/leg/essa/guidanceuseseinvestment.pdf

Vaughn, S., Martinez, L.R., Linan-Thompson, S., Reutebuch, C.K., Carlson, C.D., \& Francis, D.J. (2009). Enhancing social studies vocabulary and comprehension for seventh-grade English language learners: Findings from two experimental studies. Journal of Research on Educational Effectiveness, 2(4), 297-324. https://doi. org/10.1080/19345740903167018

Vaughn, S., \& Wanzek, J. (2014). Intensive interventions in reading for students with reading disabilities: Meaningful impacts. Learning Disabilities Research \& Practice, 29(2), 46-53. https://doi.org/10. 1111/ldrp.12031

What Works Clearinghouse. (2014). What Works Clearinghouse procedures and standards handbook version 3.0. Retrieved from https:// files.eric.ed.gov/fulltext/ED544775.pdf 
Wright, T.S., \& Cervetti, G.N. (2017). A systematic review of the research on vocabulary instruction that impacts text comprehension. Reading Research Quarterly, 52(2), 203-226. https://doi.org/ 10.1002/rrq.163

Submitted August 27, 2019

Final revision received February 28, 2020

Accepted March 5, 2020
DAN REYNOLDS is an assistant professor in the Department of Education and School Psychology at John Carroll University, University Heights, Ohio, USA; email dreynolds@jcu.edu. A former high school English teacher, his research focuses on all dimensions of adolescent literacy but with specific attention to how teachers can use interactional scaffolding to support adolescents in reading complex texts. 